\title{
Politicizing NIH funding: a bridge to nowhere
}

\begin{abstract}
We live in a time of increased spending, mounting debt, and few remedies for balancing the federal budget that have bipartisan support. Unfortunately, one recent target for decreased allocations of the federal budget is the NIH; the discussion of the awarded grants and the grant funding process has been skewed and altered to present medical research in an unfriendly light, and this can have very damaging repercussions. Politicizing this process could ultimately challenge human health, technology, and economic growth.
\end{abstract}

In an era of budget cutting and government debt, every aspect of public expenditure is appropriately coming under increased inspection. It is inevitable, therefore, that NIH appropriations will be questioned. Rumblings from several quarters, however, suggest that some special interests may attempt to utilize calls for budget cutting to introduce more direct congressional influence over which grants and proposals are funded. This is a politically seductive but dangerous approach that could result in the imposition of political agendas on the scientific community, a caustic mix that would threaten our still-great biomedical enterprise.

The President and Congress oversee the $\mathrm{NIH}$ and related organizations. They exert significant influence through appointment and confirmation of leadership and via budget appropriations. However, the authority of the NIH and related federal organizations to gather appropriate input and to decide upon mechanisms for investing appropriated funds in order to improve health has allowed granting decisions to be guided largely by peer review - a process that encourages and relies upon open discussion and debate among experts in the field.

Most Americans appreciate medical achievements but are unaware of the role of peer review in fostering scientific discoveries, ultimately leading to the development of new medicines and cures. The dramatic reduction in deaths from ischemic coronary disease over the past 40 years is but one example of success, resulting largely from NIH-funded research that elucidated the most basic biology of cholesterol metabolism leading to the discovery of lipid-lowering medications; fueled the development of coronary stents and the substances with which they are coated; and encouraged the analysis of interventions that improve clinical practice.

Despite the glowing success of biomedical advances in this country, attacks on NIH funding are growing. Surprisingly, the AARP (formerly known as the American Association of Retired Persons) recently released a television advertisement that chastises Congress for considering cuts in Medicare or Social Security while funding "treadmills for shrimp" (1). The elderly are in the greatest need of medical treatments and care, and the AARP would serve its membership more wisely by defending public support for the NIH. It is particularly irresponsible to identify specific funded programs, out of context, implying that Congress should or could judge the worth of these scientific proposals. Consideration of individual grants would be a wholly ineffective mechanism for cost savings given that most utilize less than $\$ 500,000$ per year, while the overall NIH budget is about $\$ 31$ billion and U.S. health care expenditures are more than $\$ 2.5$ trillion annually.

A conservative organization called the Traditional Values Coalition (TVC) has gone farther, calling for a moratorium on grants awarded by the NIH, as reported in The Hill (2), a Congressional newsletter, and Fox News (3). Like the AARP, this group chastises Congress for suggesting cuts in Medicare and Social Security while funneling "half a billion dollars" to the NIH for "questionable research" for "people who have made a career out of playing the federal grant game." The group cites a series of specific examples (some of which have been challenged for accuracy; ref. 4), such as "asking individuals to mail in their toenails in an effort to research how much toenail nicotine is present" or to perform a "survey of gay men to determine average penis sizes." The examples smack of political agenda (the article even mentions the "loony Left") and are dangerous and ominous attempts to politicize science in a manner that has already tarnished and gridlocked the workings of many aspects of Congress and government. A strong and broad-based denunciation of these attempts to encroach on scientific autonomy is demanded.

Related issues have been debated in Congress previously. In 2003, a proposed congressional amendment aimed to cut specific NIH grants. Thankfully, the amendment was defeated. Congressman David Obey (now retired) made the following comments, which are relevant today: "the day that we politicize NIH research ... that is the day we will ruin science research in this country. We have

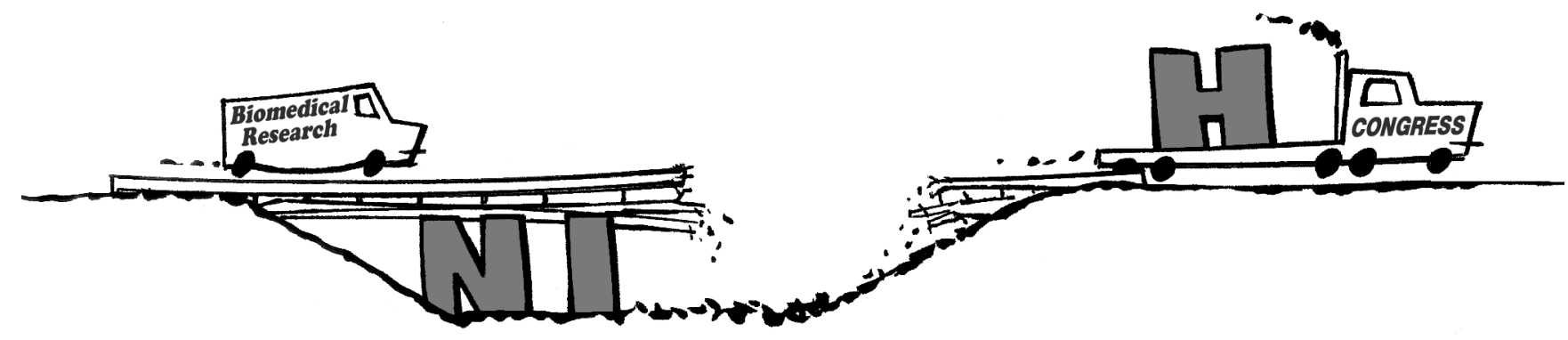


no business making political judgments about those kinds of issues ... We have $\mathrm{NIH}$ for a reason; we have peer review for a reason. I would rather trust the judgment of 10 doctors sitting around a table than I would 10 politicians sitting around a table when we decide how to allocate taxpayer money for those grants" (5).

We are sure to hear further attacks on the NIH and related agencies in the near future. Discussion and debate about the proper levels of overall appropriations are necessary, and need to acknowledge the benefits of biomedical research for the economy, for public health, and for the future. The direct impact of NIHsponsored discoveries as an economic engine fueling the biotech and pharmaceutical industries should be emphasized. A recent report estimates that public investment in NIH in 2010 led to the creation of nearly half a million jobs and produced more than 68 billion dollars in new economic activity across the country (6). Leading statesmen - including exSenator Arlen Specter and ex-Speaker of the House Newt Gingrich - have appreciated the economic and public health impact of NIH investment and have defended it. Debates about whether to cut NIH funding should also emphasize the excitement and potential of recent discoveries, including targeted therapy for cancer, cellular reprogramming and tissue regeneration, and the breathtaking pace of advancement in understanding neurodegenerative diseases. However, politically motivated focus on specific grants with the potential of a line-item review by Congress is inappropriate. It is easy to inflame public resentment with analogies to wasteful government programs such as "a bridge to nowhere," while it is a challenge to educate the lay public about the importance and potential impact of X-ray crystallography, zincfinger nucleases, or inhibitors of reverse transcriptase. The defense of scientific autonomy for government research programs must be defended on principle, and funding decisions for specific projects must continue to be made by knowledgeable experts.

At the same time, we must redouble our efforts to inform the public about the complex path by which scientific advances are conceived and translated to clinical practice. The scientific community must publicize through multiple venues (public service announcements, advertisements, the lay press) the dramatic advances that have resulted from our significant ongoing investments in the NIH. Our universities and medical schools, which benefit from federal support for research, should enhance efforts to encourage a "science savvy" public, including outreach programs for school- age children. The best approach for protection of public funding for biomedical research is to convince the American people that the money is well spent.

\section{Jonathan A. Epstein, Deputy Editor}

1. AARP. Protect Medicare and Social Security [Video]. YouTube. http://www.youtube.com/ watch?v=Pb53v5PIOcQ. Published June 15, 2011. Accessed July 25, 2011.

2. Pecquet J. Conservative group demands NIH grant moratorium, investigation. Healthwatch: The Hill's Healthcare Blog. http://thehill.com/ blogs/healthwatch/public-global-health/172011conservative-group-demands-nih-grantmoratorium-investigation. Published July 18, 2011. Accessed July 25, 2011.

3. Berger J. NIH-backed study examined effects of penis size in gay community. FoxNews. http:// www.foxnews.com/politics/2011/07/18/nihbacked-study-examined-effects-penis-size-in-gaycommunity. Published July 18, 2011. Accessed July 25, 2011.

4. Funaro V. Outrage as government funds study into sex lives of homosexuals. The Christian Post. http://www.christianpost.com/news/outrageas-government-funds-study-into-sex-lives-ofhomosexuals-52528/. Published July 19, 2011. Accessed July 25, 2011.

5. Obey D. Miscellaneous issue: Rep. David Obey speech in defense of peer review. The American Society for Cell Biology. http://www.ascb.org/ index.php?option=com_content\&view=article\&id $=3628$ Itemid $=31$. Accessed July 25, 2011.

6. Ehrlich E. An economic engine: NIH research, employment, and the future of the medical innovation sector. United for Medical Research. http://www.unitedformedicalresearch.com/wpcontent/uploads/2011/05/UMR_An-EconomicEngine.pdf. Accessed July 25, 2011. 